\title{
Distribution Channel and Microbial Characteristics of Pig By-products in Korea
}

\author{
Geunho Kang*, Pil-Nam Seong, Sungsil Moon ${ }^{1}$, Soohyun Cho, Hyoung-Joo Ham, \\ Kyoungmi Park, Sun-Moon Kang, and Beom-Young Park \\ Animal Products Research and Development Division, National Institute of Animal Science, \\ Rural Development Administration, Suwon 441-706, Korea \\ ${ }^{1}$ Sunjin Meat Academy Research Center, Seoul 134-822, Korea
}

\begin{abstract}
The distribution channel of meat by-products from the pig farm to the final consumer can include a meat processor, wholesale market, wholesaler, retailer, and butcher shop. Bacterial contamination at any of these steps remains to be a serious public health concern. The aim of this study was to evaluate the distribution channel and microbial characteristics of pig byproducts in Korea. Upon evaluation of pig by-products in cold storage, we found that the small and large intestine were significantly $(p<0.05)$ higher in $\mathrm{pH}$ value compared to the heart and liver. The total plate counts were not significantly different among offals until cold storage for $7 \mathrm{~d}$. The coliform count after $1 \mathrm{~d}$ of cold storage was significantly $(p<0.05)$ higher in small and large intestine than in the other organs. The coliform count of heart, liver, and stomach showed a higher coliform count than small and large intestine until $7 \mathrm{~d}$ of cold storage. As determined by $16 \mathrm{~S}$ rRNA sequencing, contamination of major pig by-products with Escherichia coli, Shigella spp., and other bacterial species occurred. Therefore, our results suggest that a more careful washing process is needed to maintain quality and hygiene and to ensure the safety of pig by-products, especially for small and large intestine.
\end{abstract}

Keywords: pig by-products, offal, distribution channel, microbial contamination, coliforms

\section{Introduction}

Slaughterhouses generate a significant amount of solid (skin, heart, liver, intestine, etc.) and liquid (blood) byproducts. In Korea, 14,039,960 pigs were slaughtered in 2012 (MFDS, 2013). Some pig by-products are processed by renderers, and many pig by-products are served at Korean restaurants as popular food products.

The yield of edible blood and organs from cattle is $12 \%$. When pork rinds are included, the yield is $14 \%$ for hogs (Fornias, 1996). Animal by-products such as blood, liver, lung, heart, kidney, brains, spleen, and tripe have good nutritive value (Anderson, 1988; Honikel, 2011) and constitute part of the diet in different countries worldwide (Nollet and Toldrá, 2011). The protein content of all by-products is $15-22 \%$ with few exceptions (Honikel,

\footnotetext{
*Corresponding author: Geunho Kang, Animal Products Research and Development Division, National Institute of Animal Science, Rural Development Administration, Suwon 441-706, Korea. Tel: +82-31-290-1684, Fax: +82-31-290-1697, E-mail: kangroot@korea.kr
}

2011). Animal liver is very rich in vitamins (Kim, 2011), while liver and kidney contain a wide variety of minerals and trace elements (García-Llatas et al., 2011), although cholesterol content in these organs is quite high (Bragagnolo, 2011). For instance, vitamin A content may be 20,000 retinol equivalents/ $\mu \mathrm{g}$ in pork heart (Honikel, 2011). Liver and spleen provide concentrations of vitamin $\mathrm{C}$ that are equivalent to or higher than those in apples and near the range of citrus fruits (Souci et al., 2004). Bovine blood consists of $80.9 \%$ water, $17.3 \%$ protein, $0.23 \%$ lipid, $0.0 \%$ carbohydrate, and $0.62 \%$ minerals (Duarte et al., 1999). Blood proteins, especially those found in the plasma fraction, have relevant properties, such as gelation, foaming, and emulsification, which have prompted the use of blood-derived products as value-added ingredients in the food industry and as dietary supplements (Ofori and Hsieh, 2011). For example, fractionated plasma proteins such as immunoglobulins, fibrinogen, and serum albumin may be added to food and feed ingredients because of their gelation and emulsification properties (Cofrades et al., 2000). Some plasma proteins have shown good cross-linking ability and protease inhibitory activity 
(Kang and Lanier, 1999). They have also been used to enrich products such as pasta with protein (Yousif et al., 2003).

All pig by-products are processed and washed with tap water in Korea. However, variation in the quality of pig by-products such as entrails is higher within companies, which mostly distribute them in a frozen state. Therefore, the two objectives of this study were to investigate the distribution channel of pig by-products and the microbial characteristics of washed and packed pig by-products during storage at $4^{\circ} \mathrm{C}$.

\section{Materials and Methods}

\section{Distribution channel}

The investigation of the distribution channel of Korean meat by-products was performed by visiting three major companies involved in meat by-product handling and storage.

\section{Sampling}

Pig by-products were obtained from pigs slaughtered at the meat plant of National Institute of Animal Science (NIAS) using standard procedures of NIAS-RDA, Korea. The pigs have been laraged during for $6 \mathrm{hr}$ after transport. An electrical stunner was used to stun the pigs which were then slaughtered. Pig by-products had been collected after bleeding, scalding, dehairing, washing, skinning and evisceration. Pig by-products, such as heart, kidney, stomach, small intestine, and large intestine were washed with tap water. By-products were packed in polyethylene bags and stored at $4^{\circ} \mathrm{C}$ for $1,3,7$, or $10 \mathrm{~d}$.

\section{pH and microbiological analysis}

All samples ( $3 \mathrm{~g}$ ) were homogenized using a poly-tron homogenizer (T25basic, IKA, Malaysia) with distilled water $(27 \mathrm{~mL})$. The $\mathrm{pH}$ was measured using a $\mathrm{pH}$-meter (S20K, Mettler Toledo, Swiss).

The total plate counts, coliforms counts, and Salmonella spp. counts for pig by-products were determined following the procedures of Korea Food \& Drug Administration (KFDA) Food Code (2008). Twenty-five grams of small intestine were diluted in $225 \mathrm{~mL}$ of peptone water ( $1 \mathrm{~g} / \mathrm{L}$ peptone) and homogenized for $1 \mathrm{~min}$ at normal speed in a stomacher (400 VW, Bag Mixer, France). Samples were rinsed with peptone water (1:9 dilution), and the rinse was then diluted ten-fold. The colonies that formed on the plates were counted and expressed as log colony forming units/g (CFU/g). Another $25 \mathrm{~g}$ were dilu- ted in $225 \mathrm{~mL}$ of peptone water for the isolation of coliforms. For the quantification of coliforms, samples were plated onto dry, rehydratable media $\left(3 \mathrm{M}^{\mathrm{TM}}\right.$ Petrifilm ${ }^{\mathrm{TM}}$ EC/CC Plates; 3M Microbiology) in duplicate and incubated for $24 \mathrm{~h}$ at $37^{\circ} \mathrm{C}$.

Salmonella spp. were detected in 4 steps (KFDA, 2008). Pre-enrichment in buffered peptone water at $37^{\circ} \mathrm{C}$ for 16 $20 \mathrm{~h}$ was followed by enrichment in Rappaport-Vassiliadis (RV) (Becton, Dickinson and Company, Sparks, USA) broth incubated at $42^{\circ} \mathrm{C}$ for $24 \mathrm{~h}$. The isolation was done on xylose lysine desoxycholate (XLD, Becton, Dickinson and Company, Sparks, USA) agar at $37^{\circ} \mathrm{C}$ for $24 \mathrm{~h}$. The colonies on XLD agar plates were identified by $16 \mathrm{~S}$ rRNA gene sequencing.

DNA extraction from suspected Salmonella spp. was carried out on colonies on XLD agar plates with 5\% boiling resin $(100 \mu \mathrm{L})(143-2832$, Bio-Rad, USA) and $20 \mu \mathrm{L}$ of solGent Taq buffer $(50 \mathrm{~mL}$ + proteinase $\mathrm{K} 1 \mathrm{~g}$ ) (PPK 403-1, Bioshop, Canada). The 16S rRNA was amplified using the universal primers (27F and 1492R). PCR conditions consisted of 1 cycle at $95^{\circ} \mathrm{C}$ for $15 \mathrm{~min}$ to denature DNA followed by 30 cycles of $20 \mathrm{~s}$ at $95^{\circ} \mathrm{C}, 40 \mathrm{~s}$ at $60^{\circ} \mathrm{C}$, and $90 \mathrm{~s}$ at $72^{\circ} \mathrm{C}$ and an additional cycle at $72^{\circ} \mathrm{C}$ for 5 min as a final chain elongation. Amplified DNA was analyzed using a DNA analyzer (ABI 3730XL, Applied Biosystems, USA). Sequence similarity searches were carried out using the basic local alignment search tool (BLAST) program at NCBI (Loffer et al., 2000).

\section{Statistical analysis}

The experiment was repeated three times. Data were collected for the determination of $\mathrm{pH}$, total plate counts, and coliforms counts. Analysis was conducted using a 1way ANOVA and SAS software (SAS Institute Inc., USA) followed by Duncan's multiple range tests to determine the significance of differences between treatments $(p<0.05)$.

\section{Results and Discussion}

\section{Distribution channel}

Fig. 1 shows the distribution channel of Korean pig byproducts. Meat by-products are distributed from the pig farm to the final consumer through a meat processor or wholesale market, wholesaler, retailer, and butcher shop. The supply from the farm to the wholesaler takes place in two channels: meat processors $(65.8 \%)$ and the wholesale market $(34.2 \%)$. The wholesaler supplies the retailer or chain store. The retailer then supplies the chain store, butcher shop, and restaurant. Therefore, distribution to the 


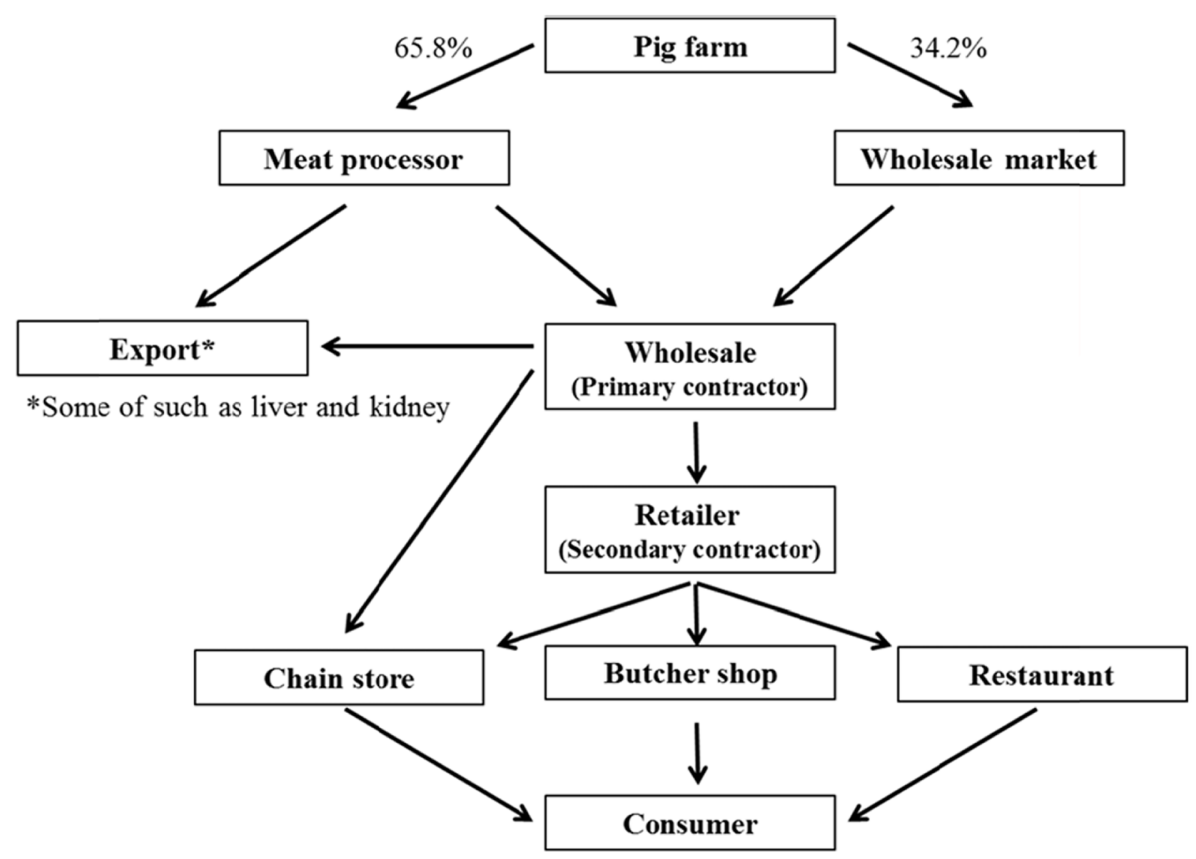

Fig. 1. The distribution channel of pig by-products in Korea.

final consumer is a 4-5 step process. Most meat by-products are distributed by wholesalers in bulk packaging. However, they are distributed to the consumer after retail packaging with wrap and polystyrene boxes. After visiting facilities that store meat by-products, we found that exterior qualities, such as color, springiness, and freshness are important for the sale of meat by-products to consumers at retail shops.

Our visiting research results suggested that the exterior quality of meat by-products is related to hygiene. In addition, we found that industrial sites were in need of technology for cleaning, packing, and storage. Therefore, more research is needed on the pig by-products processing and distribution technology.

\section{pH}

Table 1 shows the changes in $\mathrm{pH}$ of pig by-products during cold storage. The white viscera with small and large intestine exhibited significantly $(p<0.05)$ higher $\mathrm{pH}$ than the red viscera with heart and liver during cold storage. The $\mathrm{pH}$ value of white viscera with small and large intestine increased linearly with increasing cold storage time. After $7 \mathrm{~d}$ of cold storage, $\mathrm{pH}$ levels of the white viscera with small and large intestine was favorable for microbial growth. However, $\mathrm{pH}$ levels of red viscera with heart and liver remained below 7 until the 10th day of cold storage. This result suggests that stomach, small intestine, and large intestine require more careful cleaning than the other pig by-products because of the difficulty in maintaining freshness of pig by-products at a $\mathrm{pH}$ of 7 or greater.

Finally, $\mathrm{pH}$ in living muscle is near 7.0 and drops to 5.5-5.6 within $24 \mathrm{~h}$ after slaughtering. High final $\mathrm{pH}$ values result when the animals are exhausted during transportation (Becerril-Herrera, 2009). In most meat by-pro-

Table 1. Changes in $\mathrm{pH}$ of pig by-products during cold storage at $4^{\circ} \mathrm{C}$

\begin{tabular}{|c|c|c|c|c|c|}
\hline \multirow{2}{*}{ Items } & \multicolumn{4}{|c|}{ Storage time (day) } & \multirow{2}{*}{ SEM } \\
\hline & 1 & 3 & 7 & 10 & \\
\hline Heart & $6.30^{\mathrm{Dc}}$ & $6.61^{\mathrm{Bab}}$ & $6.56^{\mathrm{Bbc}}$ & $6.83^{\mathrm{Ba}}$ & 0.06 \\
\hline Liver & $6.53^{\mathrm{Ca}}$ & $6.51^{\mathrm{Ba}}$ & $6.47^{\mathrm{Ba}}$ & $6.06^{\mathrm{Cb}}$ & 0.04 \\
\hline Stomach & $6.79^{\mathrm{Bb}}$ & $6.95^{\mathrm{Ab}}$ & $7.15^{\mathrm{Aa}}$ & $7.18^{\mathrm{Aa}}$ & 0.04 \\
\hline Small intestine & $6.84^{\mathrm{ABc}}$ & $6.88^{\mathrm{Ac}}$ & $7.11^{\mathrm{Ab}}$ & $7.31^{\mathrm{Aa}}$ & 0.04 \\
\hline Large intestine & $6.96^{\mathrm{Ab}}$ & $7.00^{\mathrm{Aab}}$ & $7.09^{\mathrm{Aab}}$ & $7.18^{\mathrm{Aa}}$ & 0.04 \\
\hline SEM & 0.04 & 0.04 & 0.05 & 0.07 & \\
\hline
\end{tabular}

${ }^{\mathrm{A}-\mathrm{D}}$ Means with different superscripts within a same column differ significantly $(p<0.05)$.

${ }^{\mathrm{a}-\mathrm{c}}$ Means with different superscripts within a same row differ significantly $(p<0.05)$. 
ducts, $\mathrm{pH}$ remains high after slaughtering, allowing microbial spoilage to take place. Therefore, $\mathrm{pH}$ is a determining factor of by-product spoilage.

\section{Microbiological characteristics}

To determine and quantify bacterial contamination of pig by-products, we cultured samples of products in cold storage for various durations. Table 2 shows the changes in total plate counts of pig by-products during cold storage. The total plate counts did not vary significantly among offals until cold storage for $7 \mathrm{~d}$. However, the red viscera with liver and stomach had significantly $(p<0.05)$ lower total plate counts than the white viscera with small and large intestine after cold storage for $10 \mathrm{~d}$. The initial total plate counts from the large intestine were higher than those from the other organs. After cold storage for $3 \mathrm{~d}$, total plate counts from stomach, small and large intestine were higher than those from the heart and liver. This result suggests that stomach, small and large intestine required more careful cleaning than the other pig by-products, presumably because stomach, small intestine, and large intestine require a lot of cleaning for the removal of blood, indigestible feed, feces, etc.

Table 3 shows the changes in coliform counts of pig by-products during cold storage. The coliform count after $1 \mathrm{~d}$ of cold storage was significantly $(p<0.05)$ higher in small and large intestine than in the other organs. The coliform count of red viscera with heart, liver, and stomach showed lower coliform counts than white viscera with small and large intestine until $7 \mathrm{~d}$ of cold storage. Particularly, the heart sample was lower in coliform count than the other samples for the duration of cold storage. The coliform counts from small and large intestine were $10^{3}-10^{4} \mathrm{CFU} / \mathrm{g}$ for the duration of cold storage. Conversely, our results indicate that edible storage of the heart and liver is appropriate until $7 \mathrm{~d}$ of cold storage the perspective of coliform levels. Coliform counts from white viscera with small and large intestine are unacceptable after $1 \mathrm{~d}$ of cold storage.

The organs of livestock should be removed within 30 min of bleeding, but they usually remain with the carcass until that time. Bijker (1981) illustrated a drastic increase in the bacterial growth curve when products were stored at $4^{\circ} \mathrm{C}$ compared to that of similar products stored at $2^{\circ} \mathrm{C}$. Even at $2^{\circ} \mathrm{C}$, bacterial numbers were altered during $5 \mathrm{~d}$ of storage of beef, pork, and lamb organs, as reported by Hanna et al. (1982). The freezing of liver, kidney, and heart for $4 \mathrm{~d}$ did not significantly decrease the bacterial numbers in these products (Hanna et al., 1982). These previous studies demonstrate that the reduction of initially high bacterial numbers is very important for shelflife extension of animal by-products.

Tables 4, 5, 6, 7, and 8 show bacterial strains that most closely match $16 \mathrm{~S}$ rRNA sequences detected in major pig

Table 2. Changes in total plate counts (CFU/g) of pig by-products during cold storage at $4^{\circ} \mathrm{C}$

\begin{tabular}{cccccc}
\hline \hline \multirow{2}{*}{ Items } & \multicolumn{2}{c}{ Storage time (day) } & \multirow{2}{*}{ SEM } \\
\cline { 2 - 4 } & 1 & 3 & 7 & 10 & $1.60 \times 10^{4 \mathrm{Ba}}$ \\
\hline Heart & $0 \times 10^{\mathrm{tb}}$ & $8.89 \times 10^{\mathrm{lb}}$ & $4.13 \times 10^{3 \mathrm{ab}}$ & $2,367.35$ \\
Liver & $4.44 \times 10^{2 \mathrm{~b}}$ & $0 \times 10^{1 \mathrm{~b}}$ & $1.73 \times 10^{4 \mathrm{ab}}$ & $1.50 \times 10^{5 \mathrm{ABa}}$ & $24,976.22$ \\
Stomach & $4.44 \times 10^{1 \mathrm{~b}}$ & $6.19 \times 10^{3 \mathrm{~b}}$ & $1.48 \times 10^{5 \mathrm{a}}$ & $1.86 \times 10^{4 \mathrm{Bb}}$ & $20,832.58$ \\
Small intestine & $4.17 \times 10^{2 \mathrm{~b}}$ & $6.40 \times 10^{4 \mathrm{~b}}$ & $2.21 \times 10^{5 \mathrm{ab}}$ & $3.72 \times 10^{5 \mathrm{aa}}$ & $50,176.18$ \\
Large intestine & $7.64 \times 10^{3}$ & $1.76 \times 10^{4}$ & $5.77 \times 10^{5}$ & $1.60 \times 10^{5 \mathrm{AB}}$ & $114,748.89$ \\
SEM & 1,275 & 10,976 & 111,379 & 40,797 & \\
\hline
\end{tabular}

${ }_{\mathrm{A}-\mathrm{B}}$ Means with different superscripts within a same column differ significantly $(p<0.05)$.

${ }^{\mathrm{a}-\mathrm{b}}$ Means with different superscripts within a same row differ significantly $(p<0.05)$.

Table 3. Changes in coliforms (CFU/g) pig by-products during cold storage at $4^{\circ} \mathrm{C}$

\begin{tabular}{cccccc}
\hline \hline \multirow{2}{*}{ Items } & \multicolumn{2}{c}{ Storage time (day) } & \multirow{2}{*}{ SEM } \\
\cline { 2 - 5 } & 1 & 3 & $3.12 \times 10^{2 \mathrm{a}}$ & $1.78 \times 10^{2 \mathrm{a}}$ & 63.38 \\
Heart & $0 \times 10^{1 \mathrm{Ba}}$ & $0 \times 10^{1 \mathrm{a}}$ & $8.89 \times 10^{2 \mathrm{~b}}$ & $1.38 \times 10^{4 \mathrm{a}}$ & $1,960.73$ \\
Liver & $0 \times 10^{1 \mathrm{Bb}}$ & $0 \times 10^{1 \mathrm{~b}}$ & $1.36 \times 10^{3}$ & $3.64 \times 10^{2}$ & $1,132.93$ \\
Stomach & $4.89 \times 10^{2 \mathrm{~B}}$ & $4.91 \times 10^{3}$ & $1.28 \times 10^{4}$ & $5.10 \times 10^{4}$ & $11,616.74$ \\
Small intestine & $2.10 \times 10^{3 \mathrm{AB}}$ & $4.38 \times 10^{4}$ & $1.26 \times 10^{4 \mathrm{ab}}$ & $3.25 \times 10^{4 \mathrm{a}}$ & $4,296.73$ \\
Large intestine & $5.77 \times 10^{3 \mathrm{Ab}}$ & $1.15 \times 10^{4 \mathrm{ab}}$ & 2,425 & 8,785 & \\
SEM & 667.9 & 7,691 & & \\
\hline
\end{tabular}

${ }_{\mathrm{A}-\mathrm{B}}$ Means with different superscripts within a same column differ significantly $(p<0.05)$.

${ }^{a-b}$ Means with different superscripts within a same row differ significantly $(p<0.05)$. 
Table 4. Closest species of $16 \mathrm{~S}$ rRNA sequence similarities from bacterial strains isolated from pig heart

\begin{tabular}{ccccc}
\hline \hline Strain & Closest species & Accession no. & Similarity (\%) & Length (bp) \\
\hline P33 & Escherichia coli & JN578644 & 99 & 1538 \\
HDDMG04 & Shigella sonnei & EU723820 & 99 & 1507 \\
4096 & Shigella sp. & FJ405324 & 99 & 1503 \\
\hline
\end{tabular}

Table 5. Closest species of $16 \mathrm{~S}$ rRNA sequence similarities from bacterial strains isolated from pig liver

\begin{tabular}{ccccc}
\hline \hline Strain & Closest species & Accession no. & Similarity (\%) & Length (bp) \\
\hline P33 & Escherichia coli & JN578644 & 99 & 1538 \\
HDDMG04 & Shigella sonnei & EU723820 & 99 & 1507 \\
4096 & Shigella sp. & FJ405324 & 99 & 1503 \\
\hline
\end{tabular}

Table 6. Closest species of 16S rRNA sequence similarities from bacterial strains isolated from pig stomach

\begin{tabular}{ccccc}
\hline \hline Strain & Closest species & Accession no. & Similarity (\%) & Length (bp) \\
\hline LW1655F+ & Escherichia coli & AY616658 & 100 & 1517 \\
131 & Escherichia coli & JN180964 & 98 & 1505 \\
203 & Escherichia coli & JN180969 & 98 & 1505 \\
FBD002 & Shigella flexneri & EU009187 & 99 & 1542 \\
29 & Shigella sp. & GU968176 & 99 & 1505 \\
\hline
\end{tabular}

Table 7. Closest species of $16 \mathrm{~S}$ rRNA sequence similarities from bacterial strains isolated from pig small-intestine

\begin{tabular}{|c|c|c|c|c|}
\hline Strain & Closest species & Accession no. & Similarity (\%) & Length (bp) \\
\hline No22 & Escherichia coli & AB604197 & 99 & 1511 \\
\hline 160 & Escherichia coli & JN180967 & 99 & 1505 \\
\hline Y31 & Escherichia coli & JN578646 & 99 & 1538 \\
\hline K176 & Escherichia coli & JN644544 & 99 & 1529 \\
\hline LW1655F+ & Escherichia coli & AY616658 & 99 & 1517 \\
\hline WAB1911 & Escherichia coli & AM184252 & 99 & 1482 \\
\hline HDDMG05 & Escherichia coli & EU723821 & 99 & 1512 \\
\hline 123 & Escherichia coli & JF910107 & 99 & 1498 \\
\hline ATCC 43893 & Escherichia coli & HM194886 & 99 & 1501 \\
\hline DP170 & Escherichia coli & JF895181 & 99 & 1500 \\
\hline 114 & Escherichia coli & JN180963 & 99 & 1505 \\
\hline 203 & Escherichia coli & JN180969 & 99 & 1505 \\
\hline Acj 212 & Escherichia coli & AB480776 & 99 & 1508 \\
\hline JCM 24008 & Escherichia coli & AB548581 & 99 & 1497 \\
\hline NBRC 13891 & Escherichia coli & AB680517 & 99 & 1467 \\
\hline MMG 3b & Escherichia coli & JN162443 & 99 & 1483 \\
\hline E52 & Shigella flexneri & HQ407229 & 99 & 1525 \\
\hline E55 & Shigella flexneri & HQ407232 & 99 & 1506 \\
\hline E58 & Shigella flexneri & HQ407235 & 99 & 1523 \\
\hline 29 & Shigella sp. & GU968176 & 99 & 1505 \\
\hline
\end{tabular}

by-products. Escherichia coli, Shigella flexneri, S. sonnei, and other species were identified in samples of heart, liver, and stomach (Table 4, 5, and 6). E. coli, S. flexneri, and other species were identified in samples of small intestine (Table 7). We determined that Citrobacter freundii, E. coli, Gamma proteobacterium, Klebsiella pneumonia, K. variicola, S. boydii, S. dysenteriae, S. flexneri, and other species were present in large intestine samples. (Table 8). From these results, we determined that contamination of major pig by-products with E. coli, Shigella spp., and other species occurred. This result suggests that various bacteria were related cross contamination during processing.

Offal of certain animals may be unsafe to consume. Some animal intestines are very high in coliform bacteria and need to be washed and cooked thoroughly to be safe for eating. In conclusion, our results suggest that a careful washing process is needed for pig by-products prior to storage to maintain quality and hygiene and ensure safety, particularly for small and large intestine products. 
Table 8. Closest species of $16 \mathrm{~S}$ rRNA sequence similarities from bacterial strains isolated from pig large-intestine

\begin{tabular}{|c|c|c|c|c|}
\hline Strain & Closest species & Accession no. & Similarity (\%) & Length (bp) \\
\hline $\mathrm{J} 49$ & Bacterium & GQ165512 & 99 & 1479 \\
\hline H1 & Citrobacter freundii & FJ768455 & 99 & 1549 \\
\hline 11 & Citrobacter freundii & DQ294288 & 99 & 1534 \\
\hline 6 & Citrobacter freundii & DQ444289 & 99 & 1534 \\
\hline 7 & Citrobacter freundii & DQ294285 & 99 & 1534 \\
\hline CDC 621-64 & Citrobacter freundii & AF025365 & 99 & 1523 \\
\hline JCM 24061 & Citrobacter freundii & AB548826 & 99 & 1497 \\
\hline KWB09-600 & Escherichia albertii & HM194877 & 99 & 1501 \\
\hline SYW001 & Escherichia coli & EF620921 & 99 & 1505 \\
\hline PGB 01 & Escherichia coli & HM486679 & 99 & 1506 \\
\hline Y38 & Escherichia coli & JN578647 & 99 & 1538 \\
\hline MMG 3b & Escherichia coli & JN162443 & 99 & 1483 \\
\hline 131 & Escherichia coli & JN180964 & 99 & 1505 \\
\hline $\mathrm{C} 2$ & Escherichia coli & AF403733 & 99 & 1507 \\
\hline Acj 212 & Escherichia coli & AB480776 & 99 & 1508 \\
\hline Y31 & Escherichia coli & JN578646 & 98 & 1538 \\
\hline No22 & Escherichia coli & AB604197 & 98 & 1511 \\
\hline SSCT59 & Gamma proteobacterium & AB210976 & 99 & 1500 \\
\hline SSCT62 & Gamma proteobacterium & AB210973 & 99 & 1506 \\
\hline 319 & Klebsiella pneumoniae & AB513734 & 99 & 1501 \\
\hline 211 & Klebsiella pneumoniae & GQ259887 & 99 & 1503 \\
\hline T89 & Klebsiella pneumoniae & HQ407264 & 99 & 1522 \\
\hline D3S & Klebsiella sp. & GU259534 & 99 & 1533 \\
\hline C109 & Klebsiella variicola & HQ407284 & 99 & 1548 \\
\hline $5216-70$ & Shigella boydii & AY696668 & 98 & 1499 \\
\hline FBD015 & Shigella dysenteriae & EU009186 & 98 & 1542 \\
\hline FBD014 & Shigella dysenteriae & EU009185 & 98 & 1542 \\
\hline FBD002 & Shigella flexneri & EU009187 & 99 & 1542 \\
\hline E58 & Shigella flexneri & HQ407235 & 99 & 1523 \\
\hline E55 & Shigella flexneri & HQ407232 & 99 & 1506 \\
\hline E52 & Shigella flexneri & HQ407229 & 99 & 1525 \\
\hline AU65 & Shigellasonnei & EF032687 & 99 & 1505 \\
\hline
\end{tabular}

\section{Acknowledgements}

This work was carried out with the support of "Cooperative Research Program for Agriculture Science \& Technology Development (Project title: Development of storage and distribution technology for meat by-products, Project No. 90697403)" Rural Development Administration, Republic of Korea.

\section{References}

1. Anderson, B. A. (1988) Composition and nutritional value of edible meat by-products. In: Edible meat by-products. Pearson, A. M. and Duston, T. R. (ed). Elsevier Applied Science. London. UK. pp. 15-45.

2. Becerril-Herrera, M., Mota-Rojas, D., Guerrero-Legarreta, I., Schunemann de Aluja, A., Lemus-Flores, C., González-Lorenzo, M., Ramírez-Necoechea, R., and Alonso-Spilbury, M. (2009) Relevant aspects of swine welfare in transit. Vet. Méx.
40, 315-329.

3. Bijker, P. G. H. (1981) Hygienic aspects of edible offals. Ph. D. thesis, Utrecht Univ., Utrecht, The Netherlands.

4. Bragagnolo, N. (2011) Analysis of cholesterol in edible animal by-products. In: Handbook of analysis of edible animal byproducts. Nollet, L. M. L. and Toldra F. (ed) CRC Press, NY, pp. 43-63.

5. Cofrades, S., Guerra, N. I. A., Carballo, J., Fernández-Martin, F., and Jiménez-Colmenero, F. (2000) Plasma protein and soy fiber content effect on bologna sausage properties as influenced by fat levels. J. Food Sci. 65, 281-287.

6. Duarte, R. T., Carvalho Simoes, M. C., and Sgarbieri, V. C. (1999) Bovine blood components: Fractionation, composition, and nutritive value. J. Agric. Food Chem. 47, 231-236.

7. Fornias, O. V. (1996) Edible by-products of slaughter animals. FAO. Animal production and health. Paper 123, Rome.

8. García-Llatas, G., Alegría, A., Barberá, A., Barberá, R., and Farré, R. (2011). Minerals and trace elements. In: Handbook of analysis of edible animal by-products. Nollet, L. M. L. and Toldra F. (ed) CRC Press, NY, pp. 183-203. 
9. Hanna, M. O., Smith, G. C., Savell, J. W., McKeith, F. K., and Vanderzart, C. (1982) Microbial flora of livers, kidneys and hearts from beef, pork and lamb. J. Food Prot. 45, 63-73.

10. Honikel, K. (2011) Composition and calories. In: Handbook of analysis of edible animal by-products. Nollet, L. M. L. and Toldra F. (ed) CRC Press, NY, pp. 105-121.

11. Kang, I. S. and Lanier, T. C. (1999) Bovine plasma proteins functions in surimi gelation compared with cysteine protease inhibitors. J. Food Sci. 64, 842-846.

12. KFDA (2008) Korean Food Standard Code. Korea Food \& Drug Administration, Seoul, Korea. pp. 74-114.

13. Kim, Y. N. (2011) Vitamins. In: Handbook of analysis of edible animal by-products. Nollet, L. M. L. and Toldra F. (ed) CRC Press, NY, pp. 161-182.

14. Loffler, F. E., Sun, Q., Li, J., and Tiedje, J. (2000) 16S rRNA gene-base detection of tetrachoroethene-dechlorinating desulfuromonase and dehaloccoides species. Appl. Environ. Mic- robiol. 66, 1369-1374.

15. MFDS (Ministry of Food and Drug Safety) (2013) Food \& Drug Statistical Yearbook. The 15. p. 245.

16. Nollet, L. M. L. and Toldrá, F. (2011) Introduction. Offal meat: Definitions, regions, cultures, generalities. In: Handbook of analysis of edible animal by-products. Nollet, L. M. L. and Toldrá, F. (ed) CRC Press, NY, pp. 105-121.

17. Ofori, J. A. and Hsieh, Y. H. P. (2011) Blood-derived products for human consumption. Revelation Sci. 1, 14-21.

18. Souci, S. W., Fachmann, W., and Kraut, H. (2004) Der kleine SFK, in Lebensmitteltabelle fr die Praxis, $3^{\text {rd }}$ ed., Wiss. Verlagsgesellschaft, Stuttgart, Germany.

19. Yousif, A. M., Cranston, P., and Deeth, H. C. (2003) Incorporation of bovine dry blood plasma into biscuit flour for the production of pasta. LWT-Food Sci. Technol. 36, 295-302.

(Received 2014.9.1/Revised 2014.10.18/Accepted 2014.10.18) 